\title{
Students' Critical Thinking Skills in Chemistry Learning Using Local Culture-Based 7E Learning Cycle Model
}

\section{Nyoman Suardana}

Dr., Ganesha University of Education, Indonesia, nyoman.suardana@undiksha.ac.id

\section{Wayan Redhana}

Prof., Ganesha University of Education, Indonesia, redhana.undiksha@gmail.com

\section{A. A. Istri Agung Rai Sudiatmika}

Dr., Ganesha University of Education, Indonesia, $r$ _sudiatmika@yahoo.co.id

\section{Nyoman Selamat}

Ganesha University of Education, Indonesia, barlats@yahoo.co.id

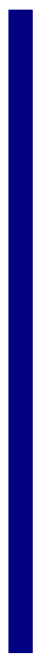

This research aimed at describing the effectiveness of the local culture-based 7E learning cycle model in improving students' critical thinking skills in chemistry learning. It was an experimental research with post-test only control group design. The population was the eleventh-grade students of senior high schools in Singaraja, Indonesia. The sample included 111 students; 57 students as the experimental group and 54 students as the control group. The students in the experimental group learned through the local culture-based $7 \mathrm{E}$ learning cycle model, whereas the ones in the control group learned through the discovery learning model. The data on the students' critical thinking skills were collected through the critical thinking skills test. The data were analyzed through descriptive and inferential analysis, namely: Independent Sample T-Test for normal and homogeneous data, but Mann-Whitney U-Test for not normal and/or not homogeneous data. The results showed that the average score of students' critical thinking skills on the experimental and control groups were 64,5 and 55,3 respectively. The average score of the students' critical thinking skills on the experimental and control groups in the high-level school were 70.0 and 58.4, respectively, but in low-level school, they were 58.7 and 50.8 respectively.

Keywords: critical thinking skills, 7E learning cycle, local culture, discovery learning, senior high school 


\section{INTRODUCTION}

The 21st century is globalization era. In this era, the development of science, technology, and the information is taking place very fast and there is free competition among the nations in the world. To anticipate and win this competition, Indonesian people have to prepare themselves by growing and developing many competencies or skills. There are many skills needed in the 21 st century, namely: 1) analytical skills (critical thinking, problem-solving, decision making, research, and inquiry); 2) interpersonal skills (communication, collaboration, leadership and responsibility); 3) ability to execute (initiative and self-direction, productivity); 4) information processing (information literacy, information and communication technology (ICT) literacy, digital citizenship, ICT operations and concepts); 5) capacity for change (creativity/innovation, adaptive learning/learning to learn, flexibility); 6) living in the world (citizenship/civic literacy, life, and career, personal and social responsibility); and 7) core subjects and 21 st century themes (mastery of core academic subjects, global awareness, finance, economy, business, and entrepreneurial literacy, health literacy, environmental literacy (Jeremy, Teresa, Nou Xi, \& Jonathan, 2013).

Critical thinking skills are parts of analytical skills or higher order thinking skills. These skills include the skills of analyzing arguments, making inferences using inductive or deductive reasoning, judging or evaluating, and making decisions or solving problems (Lia, 2011). Critical thinking skills are non-negotiable requirements for human service professions to meet the needs of today's society and to deal with the complexities of real-life problems (Ahuna, Buffalo, \& Kiener, 2014; Page \& Mukherjee, 2006). However, most of the human resources have low critical thinking skills. The teachers' critical thinking skills of the Social Studies Textbook in Iran are not satisfactory (Hashemi, 2011). Furthermore, Serin (2013) found that the first-year teacher candidates' critical thinking skills in the Turkish Republic are at a very low level and the critical thinking skills increase as candidates progress to upper classes and semesters. The Study Trends in International Mathematics and Science Study (TIMSS) year 1999, 2003, 2007, and 2011 showed that Indonesian students obtained low level in science literacy, namely: ranking 32 from 38 countries, 37 from 46 countries, 35 from 49 countries, and 40 from 42 countries respectively (Sadewo, 2014). Furthermore, the study conducted by the Programme for International Student Assessment (PISA) in 2000, 2003, 2006, and 2009 in science literacy showed that Indonesian students obtained ranking 38 from 41 countries, 38 from 40 countries, 50 from 57 countries, 60 from 65 countries (Litbang Kemdikbud, 2015). The study conducted by PISA 2012 showed that Indonesian students obtained ranking 64 from 65 countries (Kompas, December 2013). The lower critical thinking skills are also obtained by the students of a senior high school in Buleleng Regency of Bali Province, Indonesia. The research showed that the average score of the critical thinking skills of senior high school students in high, medium, and low levels were 59.0 (enough category), 43.1 (low category), and 34.7 (very low category) respectively (Suardana \& Selamat, 2012). These cases show that the quality of human resources is still low. 
Many efforts had been made by the Indonesian government to increase the quality of human resources through improvement of education such as revising curriculum, conducting in-service training for teachers, seminar, and workshop. Recently, Indonesia has implemented the new curriculum, namely 2013 curriculum. In this curriculum, all of the learning processes must be conducted using the scientific approach. In the implementation of the scientific approach, many learning models have been conducted by the senior high school teachers in Singaraja, Bali, Indonesia such as 1) problembased learning $(71.4 \%), 2)$ discovery learning $(50 \%), 3)$ cooperative learning $(21.4 \%)$, 4) inquiry learning $(14.3 \%), 5)$ project-based learning $(14.3 \%), 6)$ contextual learning $(7.1 \%)$, and 7$)$ problem solving $(7.1 \%)$ (Suardana \& Selamat, 2014). On the other hand, many researchers had attempted to study the effectiveness of learning models to increase the students' achievement such as the critical thinking skills of students. Azizmalayeri, Jafari, Sharif, Asgari, and Omidi (2012) found that there was a significant influence of guided inquiry teaching method on the total critical thinking score and conclusion and inference of subscales. The same result was found by Fuad, Zubaidah, Mahanal, and Suarsini (2017); there was a difference in critical thinking skills among the students who were taught using the Differentiated Science Inquiry model combined with the mind map, Differentiated Science Inquiry instructional model, and conventional model. The highest critical thinking skills were obtained on the students who were taught using the Differentiated Science Inquiry model combined with the mind map. Furthermore, Sinaga and Feranie (2017) found that variations in non-traditional writing tasks which included writing types, authentic audiences, text production, and content given to the students successfully increased their critical thinking skills. Zhou, Huang, and Tian (2013) stated that there were no significant differences in the total score, evaluation, and inference of the California Critical Thinking Skills Test between the task-based learning and lecturing teaching methods, but its findings provided an effective way for chemistry teachers to improve the students' critical thinking skills. On the other hand, Ahuna, Buffalo, and Kiener (2014) stated that students' critical thinking skills could be directly taught in education preparation programs such as considering the point of view, recognizing assumptions, evaluating data, extrapolating consequences, understanding concepts, and synthesizing new information.

The other learning model that can be conducted to improve the students' critical thinking skills is the 7E learning cycle (Elicitation, Engagement, Exploration, Explanation, Elaboration, Evaluation, and Extension). This model had been expanded from 5E learning cycle model by adding two more phases (Elicitation phase and Extension phase) by Eisenkraft (2003). The description of this model is shown as follows (Eisenkraft, 2003; Siribunnam \& Tayraukham, 2009). (1) In the elicitation phase, the students are motivated to express their own knowledge. After that, the learning will be planned according to the students' knowledge. (2) In the engagement phase, the students must be motivated to be curious to learn, such as using interesting videos, pictures, or stories to tell them before studying. (3) In exploration phrase, the students are given an opportunity to observe, identify variables, design an investigation, interpret results, formulate a hypothesis, and organize conclusion. (4) In the explanation phase, the students explain and introduce concepts and terms, and summarize the results 
found in the exploration phase. (5) In the elaboration phase, the students are given chance to apply the new knowledge found or even conclusion to explain another case. This phase can generate new problems for the next investigation. (6) In the evaluation phase, the students are evaluated by any technique to find out what students know after learning. (7) In the extension phase, the students are encouraged to relate and apply concepts learned in everyday life.

Many researchers had studied 7E learning cycle model. The research showed that 7E learning cycle could improve the students' critical thinking skills (Indriyani, 2013; Hartono, 2013, Fembriani, Khumedi, \& Anni; 2015, Partini, Budijanto, \& Bachri, 2017); science process skills (Susilawati, Maknun, \& Rusdian, 2010; Widjajanti, Marfuatun, \& Utomo, 2011; Johan, 2012; Suardana, 2013); cognitive achievement (Widjajanti et al., 2011; Johan, 2012; Suardana, 2013: Suardana, Liliasari, \& Ismunandar, 2013); and scientific attitude (Johan, 2012). In order that the 7E learning cycle gives more motivation and meaningful learning to students, it is very important to integrate it with local cultures, such as the Balinese culture. The local culture of students is very important in learning. Cobern and Aikenhead (1996) and Wahyudi (2007) stated that the positive influence of local culture will happen if the learning science material in school is relevant to the students' culture. While the negative influence of local culture will happen if the learning science material in school is not relevant to the students' culture. The examples of Balinese local cultures that are relevant to learning chemistry are nginang (eating betel vine), traditional vinegar production, and traditional production of table salt (Suardana, 2014). These local cultures have functioned as media and learning stimuli to motivate and help students construct new knowledge.

The objective of this research is describing the effectiveness of the local culture-based 7E learning cycle model in improving students' critical thinking skills in chemistry learning. To know the effectiveness of this model, the local culture-based 7E learning cycle model was compared to regular learning, that is, discovery learning. Discovery learning model has six phases; those are (1) stimulation phase, (2) problems statement phase, (3) data collection phase, (4) data processing phase, (5) verification phase, and (6) generalization phase.

\section{METHOD}

\section{Research design}

This research used the experimental method with post-test only control group design. The research was begun by developing the learning tools by referring to the 4D (Define, Design, Develop, and Disseminated) model of Thiagarajan et al (1974). In the developing stage, the evaluation learning tools were used to conduct the experimental research.

\section{Participants}

The population of this research included the eleventh-grade students of senior high schools (SMA) in Singaraja-Bali, Indonesia. The sample was collected using the cluster random sampling. The sample included 111 students; 57 students as the experimental 
group (EG) and 54 students as the control group (CG). There were two senior high schools used as the samples; they were SMAN 1 Singaraja (high-level school; a former pioneering international class) and SMAN 3 Singaraja (low-level school). In SMAN 1 Singaraja, the sample included 63 students; 32 students as EG and 31 students as CG. In SMAN 3 Singaraja, the sample included 48 students; 25 students as EG and 23 students as CG. The students in the EG learned through the local culture-based 7E learning cycle model and the students in the CG learned through the discovery learning model. This research was conducted in the even semester on academic year 2015/2016.

\section{Data Collection}

The data of this research were the scores of the students' critical thinking skills, which were collected using the critical thinking skill test; 25 items of objective test and 2 items of essay test. The critical thinking skill test was developed from Ennis Indicators (1985).

\section{Data Analysis}

The data were analyzed through descriptive and inferential analysis, namely: the Independent Sample T-Test for the normal distribution and homogeneous data, but the Mann-Whitney U-Test for not normal distribution and/or not homogeneous data. The inferential analysis was conducted with a 5\% significance level. The normality of data distribution was tested using the Kolmogorov-Smirnov Test. The homogeneity of variance data was tested using the Levene's Test of Equality of Error Variances.

\section{FINDINGS}

The critical thinking skills of the students who learned using the local culture-based $7 \mathrm{E}$ learning cycle model were better than those obtained through the discovery learning model, either in high-level school or in low-level school. The average score of critical thinking skills of the students who learned through the local culture-based $7 \mathrm{E}$ learning cycle model was 70 (good category) in high school level and 58.7 (enough category) in low-level school. The distribution of the students' critical thinking skills is shown in Table 1.

Table 1

The distribution of students' critical thinking skills

\begin{tabular}{llllllll}
\hline \multirow{2}{*}{ No. } & \multirow{2}{*}{$\begin{array}{l}\text { Score of Critical } \\
\text { Thinking Skills }\end{array}$} & \multicolumn{2}{l}{$\begin{array}{l}\text { SMAN 1 } \\
\text { Singaraja }\end{array}$} & \multicolumn{2}{l}{ SMAN 3 Singaraja } & \multirow{2}{*}{ Total } \\
\cline { 3 - 8 } & & EG & CG & EG & CG & EG & CG \\
\hline 1 & Sum of Samples (N) & 32 & 31 & 25 & 23 & 57 & 54 \\
\hline 2 & Mean & 70.0 & 58.4 & 58.7 & 50.8 & 64.5 & 55.3 \\
\hline 3 & Standard Deviation & 6.6 & 14.6 & 8.3 & 9.4 & 8.9 & 12.9 \\
\hline 4 & Minimum & 53.6 & 14.3 & 39.3 & 35.7 & 39.3 & 14.3 \\
\hline 5 & Maximum & 82.1 & 78.6 & 71.4 & 64.3 & 82.1 & 78.6 \\
\hline
\end{tabular}

The normality of the data distribution of the critical thinking skills of the students in the experimental group and control group were tested using the Kolmogorov-Smirnov Test. The homogeneity of variance data was tested using the Levene's Test of Equality of 
Error Variances. The summary of the result of normality and homogeneity test are shown in Table 2.

Table 2

The summary of the result of normality and homogeneity test

\begin{tabular}{lllll}
\hline \multirow{2}{*}{ Group of Data } & Normality & \multicolumn{3}{c}{ Homogeneity } \\
\cline { 2 - 3 } & $\mathrm{N}$ & Sig & Levene Statistic & Sig \\
\hline SMAN 1 Singaraja & & & & \\
\hline Experimental Group & 32 & 0.038 & \multirow{2}{*}{7.077} & \multirow{2}{*}{0.010} \\
\hline Control Group & 31 & 0.018 & \multirow{2}{*}{0.351} \\
\hline SMAN 3 Singaraja & & & & \\
\hline Experimental Group & 25 & 0.148 & \multirow{2}{*}{0.050} \\
\hline Control Group & 23 & 0.050 & & \\
\hline Total & & & 0.000 & \\
\hline Experimental Group & 57 & 0.014 & & \\
\hline Control Group & 54 & &
\end{tabular}

Based on Table 2, the data on the score of the students' critical thinking skills of the experimental and control groups in SMAN 1 Singaraja and the total score are not normally distributed (sig normality $<0.05$ ), but the data of the experimental and control groups in SMAN 3 Singaraja are normally distributed (sig normality > 0.05). Homogeneity of variance data in SMAN 1 Singaraja and the total score is not homogeneous (sig homogeneity $<0.05$ ), but the homogeneity of variance data in SMAN 3 Singaraja is homogeneous (sig homogeneity $>0.05$ ). Based on the characteristic of the data above, the data on the score of the students' critical thinking skills of SMAN 1 Singaraja and the total score is irrelevant to be analyzed using the Independent Sample T-Test, but these data can be analyzed using the Mann-Whitney U-Test. The summary of the results of analysis using the Mann-Whitney U-Test is shown in Table 3. The data on SMAN 3 Singaraja is relevant to be analyzed using the Independent Sample T-Test. The summary of the result of analysis using the Independent Sample T-Test is shown in Table 4

Table 3

The summary of the result of the Mann-Whitney U-Test

\begin{tabular}{lll}
\hline \multirow{2}{*}{ Description } & Critical Thinking Skills & \\
\cline { 2 - 3 } & SMAN 1 Singaraja & Total \\
\hline Mann-Whitney U & 244.500 & 836.000 \\
\hline Wilcoxon W & 740.500 & 2321.000 \\
\hline Z & -3.497 & -4.170 \\
\hline Asymp. Sig. (2-tailed) & 0.000 & 0.000 \\
\hline
\end{tabular}

Based on Table 3, the value of sig is $0.000<0.05$, meaning that the critical thinking skills between students who learned through the local-culture based 7E learning cycle model and those who learned through the discovery learning model are significantly different, both in high-level school and in the total schools. 
Table 4

The summary of the result of Independent Sample T-Test

\begin{tabular}{|c|c|c|c|c|c|c|c|c|}
\hline \multirow[t]{3}{*}{ Description } & $\begin{array}{l}\text { Levene's } \\
\text { Test for } \\
\text { Equality of } \\
\text { Variances }\end{array}$ & \multicolumn{7}{|c|}{ t-test for Equality of Means } \\
\hline & \multirow{2}{*}{ Sig. } & \multirow{2}{*}{$\mathrm{t}$} & \multirow{2}{*}{ df } & \multirow[t]{2}{*}{$\begin{array}{l}\text { Sig. } \\
(2- \\
\text { tailed })\end{array}$} & \multirow[t]{2}{*}{$\begin{array}{l}\text { Mean } \\
\text { Difference }\end{array}$} & \multirow[t]{2}{*}{$\begin{array}{l}\text { Std. Error } \\
\text { Difference }\end{array}$} & \multicolumn{2}{|c|}{$\begin{array}{l}95 \% \text { Confidence } \\
\text { Interval of the } \\
\text { Difference }\end{array}$} \\
\hline & & & & & & & Lower & Upper \\
\hline $\begin{array}{l}\text { Equal variances } \\
\text { assumed }\end{array}$ & $.887 \quad .351$ & -3.121 & 46 & .003 & -7.94609 & 2.54579 & -13.07049 & -2.82168 \\
\hline $\begin{array}{l}\text { Equal variances } \\
\text { not assumed }\end{array}$ & & -3.105 & 44.054 & .003 & -7.94609 & 2.55945 & -13.10414 & -2.78803 \\
\hline
\end{tabular}

Based on Table 4, the value of sig is $0.003<0.05$, meaning that the critical thinking skills of the students in low-level school who learned through the local culture-based 7E learning cycle model are significantly different from those of the students who learned through the discovery learning model. The critical thinking skills of the students who learned through the local culture-based 7E learning cycle model are better than those of the students who learned through the discovery learning model.

\section{DISCUSSION}

The research showed that the critical thinking skills of the students who learned through the local culture-based 7E learning cycle model were better than those obtained by the students who learned through the discovery learning model. The students' critical thinking skills could be improved through the local culture-based 7E learning cycle, both in the high-level category and low-level category of senior high school students. This was because the local culture-based $7 \mathrm{E}$ learning cycle model using the local culture phenomena as the media and learning stimuli could motivate and help students understand the chemistry material. In salt hydrolysis topics, for example, one of the local cultural phenomena is provided, namely the production of table salt by the salt farmers at Tejakula village, Buleleng Regency, Bali. In the salt production, the students were shown photos of salt producing stages. Table salt is not hydrolysis in water so table salt concept is a non-example concept of the salt hydrolysis. In order that the students could find salt hydrolysis concept in local culture phenomena, the salt that is hydrolyzed in water was also shown and it is often found in everyday life such as baking soda $\left(\mathrm{NaHCO}_{3}\right)$ used as the material for developing baking soda dough, ammonium sulfate in ZA (Zwavelzure Amonnia) fertilizer used by farmers to fertilize their crops. Based on the local culture phenomena, the students were asked to solve the problems and they were also asked to design practicum appropriate with the local culture and concepts discussed.

The local culture phenomena can motivate the students to learn. The students were seen very actively pose, discuss, answer and solve the problems. The local culture phenomena that are appropriate with their prior knowledge help them construct new knowledge. The contribution of the local culture in learning or in laboratory activities 
had been reported by many researchers (Baker \& Taylor, 1995; Cobern \& Aikenhead, 1996; Jegede \& Aikenhead, n.d.; Jegede \& Okebukola in Suastra, 2005; Suja et al., 2007; Selamat et al., 2009; Suastra et al., 2011); Suardana, 2010 \& 2013; Suardana et al., 2011 \& 2013; Attaran et al., 2012; Yuenyong, J. \& Yuenyong, C., 2012; Windayani, N.W.K., 2013; Munawar, M., 2013, Marheni \& Suardana, 2014).

The learning stages in the local culture-based 7E learning cycle give opportunities for the students to practice and develop critical thinking skills. The elicitation phase is intended to identify the students' prior knowledge and ensure that the students know the subjects that will be learned. This phase aims to verify their readiness to learn and to make them interested in the chemistry subject. The students' prior knowledge is explored from the local culture phenomena related to the subject that will be learned. Their prior knowledge of the subject can help and facilitate them construct new knowledge. The engagement phase is intended to attract the students' attention or generate their interest in the pose the problems, telling a story, give the demonstration, show the objects or pictures related to the local culture. This local culture is used as the learning stimuli for the students so that they learn actively. The exploration phase is intended to give students opportunity to observe, identify variables, design an investigation, interpret results, formulate a hypothesis and organize conclusion. These activities are guided by the students' local culture-based worksheet. In this phase, they learn meaningfully, practice and develop the scientific attitude. The teacher gives guidance and feedback. Besides, the teacher also evaluates their achievement. The explanation phase is intended to explain concepts, introduce concepts and terms, and summarize the results found in the exploration phase. The elaboration phase is intended to give students chance to apply the new knowledge found. This phase can generate new problems for the next investigation. The evaluation phase is intended to give the formative evaluation of the development of the students' knowledge about concepts, principles, and ability to apply the concepts. The extension phase is intended to encourage students to relate and apply the concepts learned in everyday life. Through these local culture-based seven stages of the 7E learning cycle, the students can practice and develop their critical thinking skills along the learning process. The stages of the $7 \mathrm{E}$ learning cycle are adapted from Eisenkraft (2003). The effectiveness of 7E learning cycle in improving the students' critical thinking skills had been reported by Indriyani (2013) and Hartono (2013).

The local culture-based 7E learning cycle gives opportunities for the students to design investigation such as designing practicum. In designing practicum, the students are challenged to think critically how to solve their problems. This case is relevant with what is stated by Reeve (2004) that in designing experiment, the students are encouraged to think about the procedural stages and to understand the objectives of the procedure. Therefore, the students must learn the learning material, collect information from any other resources, and discuss collaboratively their ideas to solve problems. The designing practicum is one of the inquiry activities to practice and develop the students' metacognitive skills and develop wider learning skills including the critical thinking skills (Kipnis \& Hopstein, 2007). 
The discovery learning model in the other parts, in spite of giving opportunities to students to practice and develop critical thinking skills, it does not give opportunities to the students to design practicum. The students conducted practicum according to the practicum stages in their worksheet so that they did not understand clearly every stage of the practicum conducted. The stages of the discovery learning model are as follows. The stimulation phase, students are faced with the things that make them confused. The teacher does not give generalization so the students need to conduct self-investigation. The teacher also begins learning activities by posing the questions, suggesting reading references/books, and the other learning activities intended to solve problems. Stimulation in this phase functions to prepare the learning interaction condition that can develop and help the students explore the subject matter. The problems statement phase; the teacher gives opportunities to the students to identify problem agenda that are relevant to the subject matter, then one of these is picked and formulated as the hypothesis. The data collection phase; the teacher gives opportunities to the students to collect relevant information to prove the hypothesis. The information can be collected by reading books, observing objects, interviewing resource persons, testing themselves, etc. The data processing phase; students process data and information. The data are classified, tabulated, calculated or interpreted with a certain significant level. The verification phase; the students investigate carefully to verify the hypothesis. This hypothesis is related to the result of the data processing. Verification functions to give opportunities to the students to learn creatively, to find new concepts or theory, and to link the concepts with examples in everyday life. The generalization phase; the students give opportunities to conclude the subject studied. The conclusion is utilized as the general principle and it goes into effect for all the same problems. Based on the verification result, they formulate principles that underlie generalization (adapted from Ministry of Education and Culture, 2013)

Although the critical thinking skills of students who learned through the local culturebased 7E learning cycle model were better than those obtained by the students who learned through the discovery learning model, the results were not optimal. This was caused by many obstacles in the implementation of the local culture-based7E learning cycle model. The obstacles found in the implementation of the local culture-based 7E learning cycle model were as follows. (1) Most of the students were not ready to learn the subjects although they had been given tasks to do the problems in the worksheet before learning. This caused the 7E learning cycle phases was not to be able to be conducted optimally. The implementation of the local culture-based 7E learning cycle model requires the students to be ready for learning so that they can link their prior knowledge more easily related to local culture with the knowledge that they have learned. Therefore, the students understand the subjects more easily and construct the known knowledge. (2) It was difficulty in growing the positive habit of the students to be active, as the learning results from the learning experience before tend to make the students passive. This causes the teachers to tend to conduct learning with discourse method. The local culture-based 7E learning cycle model requires the students to be active in learning because this model is a student-centered learning so the students have to learn actively. (3) It was difficulty in relating local cultures that were relevant to the 
learning materials. There were not so many local cultures that could be integrated with the learning materials. (4) The heterogeneous ability of the students causes them to find it difficult to learn the local-based 7E learning cycle model. These obstacles cause the implementation of the local culture-based 7E learning cycle model not optimal so the students' critical thinking skills could not be improved optimally. In order that their critical thinking skills can be improved optimally, all obstacles in the implementation of the local culture-based 7E learning cycle model must be eliminated by habituating the students to be active in learning. The students must be habituated to follow the localbased 7E learning cycle model so that they can use the critical thinking skills in the learning process.

\section{CONCLUSION}

Based on the results of this study, it can be concluded that the critical thinking skills of the students who learned through the local culture-based7E learning cycle model were better than those obtained by the students who learned through the discovery learning model, both students in high-level and low-level schools. The average score of the critical thinking skills of the students who learned through the local culture-based $7 \mathrm{E}$ learning cycle model and discovery learning model were 64.5 and 55.3, respectively. The average score of the critical thinking skills of the students (in high-level school) who learned through the local culture-based 7E learning cycle model and discovery learning model were 70.0 and 58.4, respectively. The average score of the critical thinking skills of the students (in low-level school) who learned through the local culture-based 7E learning cycle model and discovery learning model were 58.7 and 50.8 , respectively. The obstacles found in the implementation of the culture-based $7 \mathrm{E}$ learning cycle model were (1) most of the students were not ready to learn the subjects, (2) difficulty in growing the positive habit of the students to be active in learning, (3) difficulty in making the local culture relevant to the learning material, and (4) the heterogeneous ability of the students. It needs to explore more local culture relevant to the learning materials so that learning becomes richer. In addition, the use of local culture in learning can improve students' learning motivation.

\section{REFERENCES}

Ahuna, K.H., Buffalo, C.G.T. \& Kiener, M. (2014). A New Era of Critical Thinking in Professional Programs. Transformative Dialogues: Teaching \& Learning Journal, 7(3): $1-9$.

Attaran, M., Alias, N., \& Siraj, S. (2012). Learning Culture in a Smart School: A Case Study. Procedia-Social and Behavioral Sciences, 64, 417-423.

Azizmalayeri, K., Jafari, E.M., Sharif, M., Asgari, M., \& Omidi, M. (2012). The impact of guided inquiry methods of teaching the critical thinking of high school students. Journal of Education and Practice, 3(10), 42-48.

Baker, D., \& Taylor, P. C. S. (1995). "The Effect of Culture on the Learning of Science in Non-Western Countries: the Result of an Integrated Research Review." Journal Science Education. 17(6), 695-704. 
Cobern, W. W., \& Aikenhead, G. S. (1996). Cultural aspects of learning science. Available: http://wmich.edu/slcsp/121. HTML. [21 December 2003].

Eisenkraft, A. (2003). Expanding the 5E Model. The Science Teacher, 70(6), 56-59.

Ennis, R. (1985). Curriculum for Critical Thinking. In A. L. Costa (Eds). Developing Minds: A Resource Book for Teaching Thinking. Alexandria: Association for Supervision and Curriculum Development.

Fembriani, Khumedi \& Anni, C.T. (2015). Pengembangan Perangkat Pembelajaran IPA Model Learning Cycle 7E untuk Meningkatkan Kemampuan Berpikir Kritis. Journal of Primary Education, 4(1), 15-23.

Fuad, N. M., Zubaidah, S., Mahanal, S., \& Suarsini, E. (2017). Improving Junior High Schools' Critical Thinking Skills Based on Test Three Different Models of Learning. International Journal of Instruction, 10(1), 101-116.

Hartono. (2013). Learning Cycle-7E Model to Increase Student's Critical Thinking on Science. Jurnal Pendidikan Fisika Indonesia. 9, 58-66.

Hashemi, S. A. (2011). The Use of Critical Thinking in Social Science Textbooks of High School: A Field Study of Fars Province in Iran. International Journal of Instruction, 4(1), 63-78.

Indriyani, I. R. (2013). Pengembangan LKS Fisika Berbasis Siklus Belajar (Learning Cycle) 7E untuk Meningkatkan Hasil Belajar dan Mengembangkan Kemampuan Berpikir Kritis Pada Siswa SMA Kelas X Pokok Bahasan Elektromagnetik. Tesis. Yogyakarta: Program Pascasarjana Pendidikan Fisika Universitas Ahmad Dahlan.

Jegede, O. J., \& Aikenhead, G.S. (n.d.). Transcending Cultural Borders: Implications for Science Teaching. Available: http://www.whk.edu.hk/ cridal/misc/jegede.htm. [23 Mei 2002].

Jeremy, B., Teresa, J., Nuo Xi \& Jonathan, S. (2013). Identifying the Most Important 21st Century Workforce Competencies: An Analysis of the Occupational Information Network Research Report. New York: ETS Researcher.

Johan, B. P. (2012). Pengaruh Model Siklus Belajar 7E terhadap Keterampilan Proses IPA, Sikap Ilmiah IPA dan Prestasi Belajar IPA (Sudi pada Kelas IV SDN Kranjnigan 05 Jember). Tesis. Universitas Negeri Malang. http://karyailmiah.um.ac.id/index.php/disertasi/article/view/18929. [September $1^{\text {st }}, 2012$ ].

Kipnis, M., \& Hofstein, A. (2007). "The Inquiry Laboratory as A Source for Development of Metacognitive Skills". International Journal of Science and Mathematics Education, 6(3), 601-627.

Kompas. (2015). Skor PISA: Posisi Indonesia Nyaris Jadi Juru Kunci. Available: http://www.kopertis12.or.id/2013/12/05/skor-pisa-posisi-indonesia-nyaris-jadi-jurukunci.html. [Nopember $\left.9^{\text {th }}, 2015\right]$.

Lai, E. R. (2011). Critical Thinking: A Literature Review. Research Report. Pearson. 
Litbang Kemdikbud (2015). PISA (Programme for International Student Assessment. Available: http://litbang. kemdikbud.go.id/index./survei-interna-sional-pisa. [Nopember $\left.9^{\text {th }}, 2015\right]$.

Marheni, N. P. \& Suardana, I N. (2014). Pembelajaran Inkuiri Terbimbing Berbasis Budaya Lokal pada Pembelajaran Sains Kimia SMP. Jurnal Wahana, 8(2), 186-198.

Ministry of Education and Culture (2013). Model Pembelajaran Penemuan (Discovery Learning).

Munawar, M., Prasetyo, A. \& Pusari R.W. (2013). Pengembangan Model Pem-belajaran Inovatif melalui Pendekatan In House Training Berbasis Kearifan Budaya Lokal. Jurnal Penelitian PAUDIA, 2(1), 1-13.

Page, D., \& Mukherjee, A. (2006). Using Negotiation Exercises To Promote Critical Thinking Skills. Developments in Business Simulation and Experiential Learning. (33), 71-78.

Partini, Budijanto \& Bachri, S. (2017). Penerapan Model Pembelajaran Learning Cycle 7E untuk Meningkatkan Kemampuan Berpikir Kritis Siswa. Jurnal Pendidikan, 2(2), 268-272.

Sadewo, J. (2014). Kemana Arah Pendidikan Indonesia. Republika, 27 Februari 2014. Available: http://www. republika.co.id/berita/pendidikan/edu-action/14/02/27/n1nns0kemana-arah-pendidikan-indonesia. [Nopember $9^{\text {th }}, 2015$ ].

Selamat, I N., Redhana, I W., \& Suardana, I N. (2009). Pengembangan Buku Kerja Kimia Berbasis Peta Argumen Menggunakan Konteks Budaya Lokal untuk Meningkatkan Keterampilan Berpikir Kritis Siswa SMA. Research Report. Singaraja: Universitas Pendidikan Ganesha.

Serin, O. (2013). The critical thinking skills of teacher candidates. Turkish Republic of Northern Cyprus sampling. Eurasian Journal of Educational Research, 53, 231-248.

Sinaga, P., \& Feranie, S. (2017). Enhancing Critical Thinking Skills and Writing Skills through the Variation in Non-Traditional Writing Task. International Journal of Instruction, 10(2), 71-84.

Siribunnam, R., \& Tayraukham, S. (2009). Effects of 7-E, KWL and Conventional Instruction on Analytical Thinking, Learning Achievement and Attitudes toward Chemistry Learning. Journal of Social Sciences, 5(4), 279-282.

Suardana, I N. (2010). Pengembangan Model Praktikum Kimia Dasar Berbasis Budaya Bali untuk Meningkatkan Keterampilan Berpikir Kritis Mahasiswa Calon Guru Kimia. Desertation. Bandung: Program Pasca Sarjana Universitas Pendidikan Indonesia.

Suardana, I N. (2013). Penerapan Siklus Belajar 7E Berbasis Budaya Lokal untuk Meningkatkan Penguasaan Konsep dan Keterampilan Proses Sains Mahasiswa pada 
Pembelajaran Kimia Dasar I. Research Report. Singaraja: Universitas Pendidikan Ganesha.

Suardana, I N. (2014). Analisis Relevansi Budaya Lokal dengan Materi Kimia SMA untuk Mengembangkan Perangkat Pembelajaran Inkuiri Terbimbing Berbasis Budaya. Jurnal Pendidikan Indonesia. 3(1), 337-347.

Suardana, I N., Liliasari, Ismunandar \& Sumarna, O. (2011). Praktikum Berbasis Budaya Lokal pada Topik Asam-Basa. Jurnal Pendidikan Kimia Indonesia, 1 (1), 2835 .

Suardana, I N., Liliasari \& Ismunandar. (2013). Peningkatan Penguasaan Konsep Mahasiswa melalui Praktikum Elektrolisis Berbasis Budaya Lokal. Jurnal Pendidikan dan Pembelajaran, 20(1), 45-52.

Suardana, I N \& Selamat, I N (2012). Pengembangan Perangkat Pembelajaran Inkuiri Terbimbing Berbasis Budaya Lokal untuk Meningkatkan Keterampilan Berpikir Kritis Siswa SMA pada Mata Pelajaran Kimia (Year I). Research Report. Singaraja: Universitas Pendidikan Ganesha.

Suastra, I W. (2005). Merekontruksi Sains Asli (Indigenius Science) dalam Rangka Studi Etnogenis pada masyarakat Panglipuran Bali. Dissertation. Bandung: Program Pascasarjana Universitas Pendidikan Indonesia.

Suastra, I W., Tika, K., \& Karyasa, N. (2011). Efektivitas Model Pembelajaran Berbasis Budaya Lokal untuk Mengembangkan Kompetensi Dasar Sains dan Nilai Kearifan Lokal Di SMP. Jurnal Penelitian dan Pengembangan Pendidikan, 5(3), 258 - 273.

Suja, I W., Sudria IBN., \& Muderawan, I W. (2007). Integrasi Sains Asli (Indigeneous Science) ke dalam Kurikulum Sains Sekolah sebagai Upaya Pengembangan Pendidikan Sains Berbasis Content dan Context Budaya Bali. Research Report. Singaraja: Universitas Pendidikan Ganesha.

Susilawati, Maknun, J., \& Rusdian, D. (2010). Penerapan Siklus Belajar Hipotetikal Deduktif 7E untuk Meningkatkan Keterampilan Proses Sains Siswa SMA pada Konsep Pembiasan Cahaya. Prosiding Seminar Nasional Fisik,. 318-325.

Thiagarajan, S., Semmel, D. S., \& Semmel, M. L. (1974). Instructional, development for training teacher of exceptional children. Minnesota: Indiana University.

Widjajanti, E., Marfuatun \& Utomo, P. (2011). Upaya Peningkatan Pemahaman Konseptual dan Keterampilan Proses Ilmiah Mahasiswa pada Praktikum Kimia Fisika II melalui Model Daur Belajar 7E. Prosiding Seminar Nasional Kimia Jurusan Pendidikan Kimia FMIPA UNY. 109-118.

Wahyudi (2007). Kurikulum IPA Berbasis Budaya Lokal. [Online]. Available: http://www.duniaguru.com. [April $3^{\text {th }}, 2009$ ]. 
Windayani, N. W. K., Suardana, I N., \& Kirna, I M. (2013). Pengembangan Perangkat Pembelajaran Kimia Berbasis Budaya Lokal dan Keterampilan Berpikir Kritis. Jurnal Pendidikan Kimia Indonesia, 3(1-2), 27-35.

Yuenyong, J., \& Yuenyong, C. (2012). Connecting between culture of learning in Thai contexts and developing students' science learning in the formal setting. Procedia Social and Behavioral Sciences, 46, 5371-5378.

Zhou, O., Huang, Q., \& Tian, H (2013). Developing Students' Critical Thinking Skills by Task-Based Learning in Chemistry Experiment Teaching. Creative Education, 4(12A), 40-45. 